\title{
A new method for tracheal reconstruction
}

\author{
H. A LETRAS, V. O. B J ÖRK, G. HULT Q U IS T, \\ A N D L. RODR IG UEZ
}

From the Departments of Thoracic Surgery and Pathology, University Hospital, Uppsala, Sweden

\begin{abstract}
Various methods and materials have been tried in dealing with tubular or 'sleeve' resection of the trachea. In relatively short tracheal defects, 2-4 $\mathrm{cm}$. in clinical cases, an end-to-end anastomosis gives the most satisfactory result (Kay, 1952; Crafoord, Björk, and Hilty, 1954 ; Björk, 1955 ; Paulson and Shaw, 1955 ; Mathey, Denis, and Binet, 1960). In some cases a 'montage' operation without prosthetic material can be used (Barclay, McSwan, and Welsh, 1957) even in longer resections of up to $5-6 \mathrm{~cm}$.
\end{abstract}

To treat more extensive tubular defects the use of a prosthesis is necessary. Tracheal homografts, 'fresh' or 'pre-treated,' and aortic homografts (Jackson, O'Brien, Tuttle, and Meyer, 1950 ; Davies, Edmiston, and McCorkle, 1952 ; Rob and Bromley, 1953 ; Björk and Rodriguez, 1958) have been proved experimentally to be unsuccessful, as the graft is rejected by the tissues of the host.

Two forms of prosthesis of alloplastic material have been used both experimentally and clinically, alone or in combination with free or pedicled autogenous grafts. These are meshes (Rob and Bromley, 1953 ; Ferguson, Wild and Wangensteen, 1950 ; Swift, Grindlay and Clagett, 1952 ; Morfit, Neerken, Prevedel, Liddle, and Kircher, 1954 ; Keshishian, Blades, and Beattie, 1956; Dor and Carcassonne, 1958 ; Greenberg, 1960 ; Harrington, Beall, Morris, and Usher, 1962 ; Beall, Harrington, Greenberg, Morris, and Usher, 1962 ; Greenberg and Willms, 1962; Rob and Bateman, 1949; Ravitch, 1951 ; Brewer and Bai, 1955 ; Cummins and Waterman, 1957) and non-porous metallic or plastic tubes (Björk and Rodriguez, 1958; Keshishian et al., 1956 ; Dor and Carcassonne, 1958 ; Daniel, 1948 ; Clagett, Grindlay, and Moersch, 1948 ; Craig, Holmes, and Shabart, 1953; Rush and Cliffton, 1956; Jesseph, Stevenson, Harkins and Merendino, 1956; Pressman and Simon, 1958; Moncrief and Salvatore, 1958 ; Taber and Tomatis, 1958 ; Bell, 1960 ; Michelson, Solomon, Maun, and Ramirez, 1961 ; Aronstam, Nims, and Winn, 1961 ; Kramish, Rutherford, Morfit and Lunt, 1961 ; Longmire, 1948 ; Cotton and Penido, 1952 ; Clagett, 1956 ; Burnett, Stanley, and Stringer, 1962).

The usual causes of the almost uniformly unsuccessful results of tracheal reconstruction using a prosthesis have been (1) stricture from granulation through the mesh or at the site of anastomosis; (2) pressure necrosis from the prosthesis; and (3) stricture of the trachea after dislodgment or removal of the prosthesis.

A promising method was reported by Ekeström $(1956$; 1958); a teflon frame is embedded for five to 12 weeks subcutaneously to form an autogenous tissue tube which is used for the prosthesis.

In order to avoid the two months' delay before a tracheal reconstruction can take place and to prevent stricture from a suture granuloma at the site of the anastomosis a new method has been developed. The aim of this paper is to present this method and the experimental results obtained.

\section{METHOD}

THE INNER TUBE To prevent stricture from granulations at the site of the anastomosis to the prosthesis it is necessary to extend the prosthesis 5 to $10 \mathrm{~mm}$. on the inside of the trachea at each anastomosis. The suture to the divided tracheal end was therefore secured to a special ridge on the outside of the inner tube. Silastic reinforced by nylon and covered with dacron has been used in order to diminish the incidence of pressure necrosis (Fig. $1 \mathrm{~A}$ ). Inner tubes of teflon, known to be well tolerated, have also been used for anastomosis to the trachea (Fig. 1 B to D).

THE OUTER TUBE An outer tube was created around the rigid inner tube by pedicled pericardium wrapped around the tube and sutured to itself and to the outside of the trachea at each end. Rings were then applied over the pericardium. The aim was that the rings should become embedded in the mediastinal tissue and act as cartilage, preventing stricture of the newly formed trachea in case the inner tube should become dislodged. The rings were of two kinds, teflon rings, and rings of stainless steel covered with ivalon sponge. The teflon rings were kept in place by sutures through drill holes. 

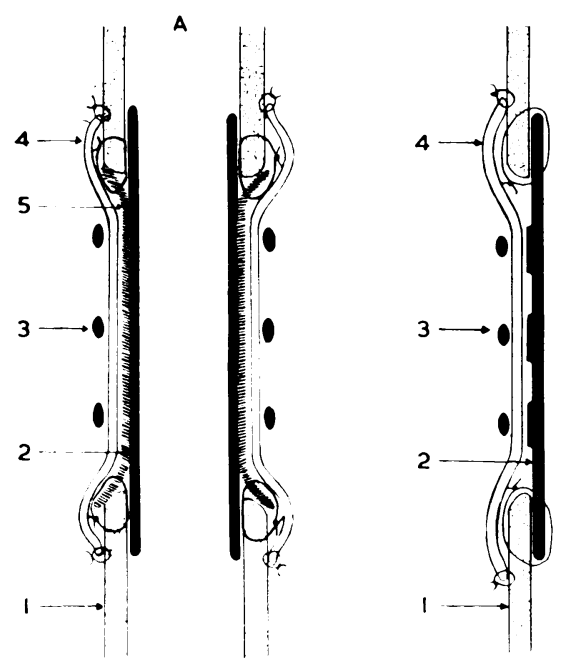

B
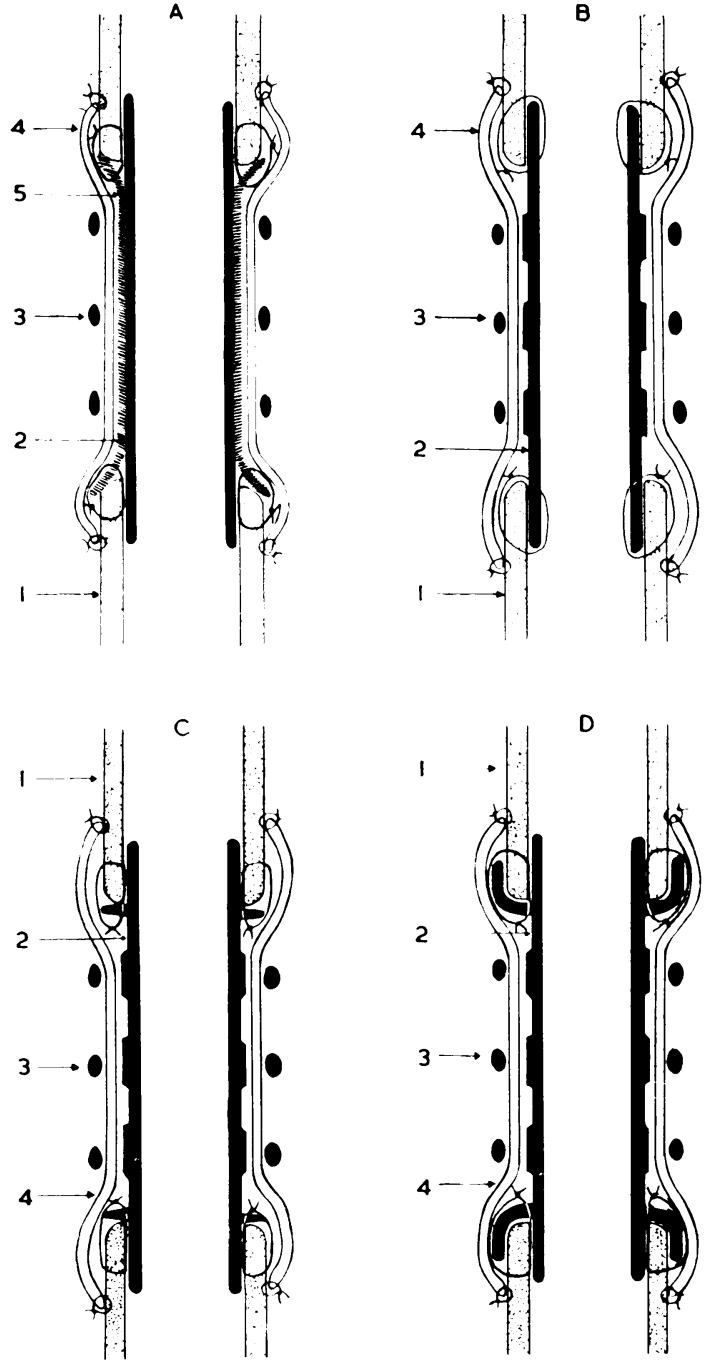

FIG. 1. Diagram showing the different prostheses (2) sutured in place covered by pedicled pericardium (4) and rings (3). A: Inner tube of silastic (2) covered with dacron (5) which is sewn on to the trachea (1). The pedicled pericardium (4) is surrounded by rings (3). B: Inner tube of teflon (2) sutured in place. $C$ : Inner tube of teflon (2) with a straight sewing ridge for fixation to the trachea (1). $D$ : Inner tube of teflon (2) with a rounded sewing ridge for enclosure of the tracheal end (1).

THE OPERATION Fifty-seven dogs were used. Anaesthesia was induced with intravenous thiopentone and a short-acting muscle relaxant (succinylcholine chloride). Nitrous oxide and oxygen were then administered through an intratracheal tube with the aid of a volume-regulated Engström respirator. Thoracotomy was performed under the fourth rib on the right
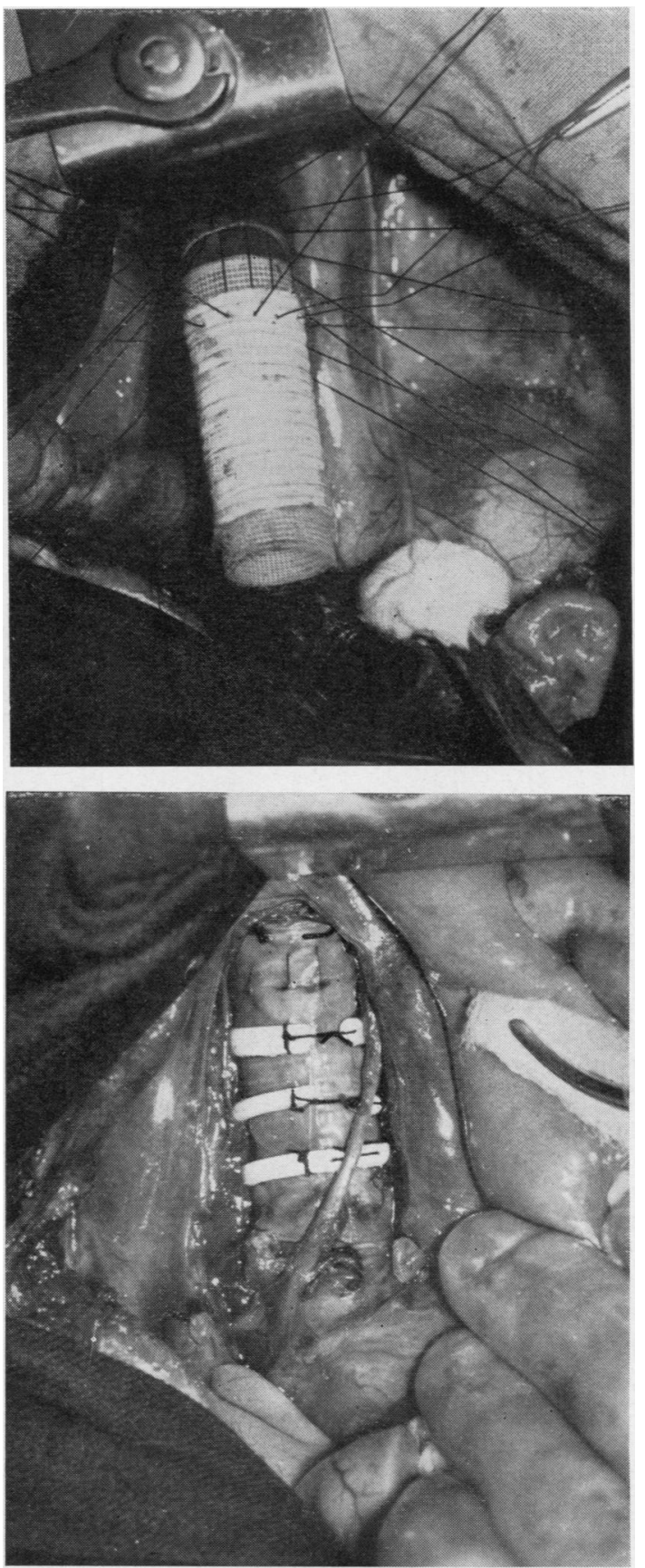

FIG. 2. (Above) The silk sutures are passed through the tube of dacron to the trachea so that the inner tube of silastic will come on the inside of the trachea, preventing stricture at the anastomosis. (Below) The inner tube is covered by a flap of pedicled pericardium and then by teflon rings. The rings are fixed by sutures through drill holes. 
side. The azygos vein was divided, the trachea liberated, and six to nine rings resected. The trachea was first divided at the cranial end and the peripheral portion was used for ventilation through a rubber tube introduced from the open thorax. The prosthesis was then sutured in position into the cranial portion of the trachea with isolated silk sutures to an airtight connexion (Fig. 2, above).

As a second step, the trachea was divided above the bifurcation, and four sutures were placed at equal distances in the trachea and secured to the prosthesis, after which ventilation could be continued at an increased volume through the tube introduced through the larynx. Air leaked around the central anastomosis until a sufficient number of sutures had been inserted.

As a third step, a pedicled flap of pericardium, with the pedicle situated cranially, thus preserving the blood supply, was created. This pericardial flap was brought behind the superior vena cava and around the prosthesis and sutured to itself and to both ends of the trachea. Then three to four rings of teflon or ivalon reinforced by stainless steel wire were placed outside the pericardium and fixed $0.5 \mathrm{~cm}$. apart by sutures (Fig. 2, below). The chest was closed with one tube for drainage, and tracheostomy was performed in all cases.

\section{RESULTS}

CONTROL GROUP A group of six dogs were used as controls. Only the inner tube was introduced and left to see how long it would stay in place. In five cases a tube of silastic covered with a nylon sewing ring was used. In four dogs the prosthesis was displaced, with stricture formation from the surrounding granulation tissue after 36 , 55, 97, and 183 days (Fig. 3). In one dog the prosthesis was removed by bronchoscopy after 50 days, which caused collapse of the trachea and death.

In the remaining dog (11) a teflon tube (Fig. 1D) was used and functioned well for four years after which the dog died during transport (Fig. 4).

Conclusion A silastic tube has a tendency to become dislodged, thus causing collapse of the trachea. A tefion tube was used successfully for tracheal replacement for four years in one dog.

GROUP A The prosthesis used was an inner tube of silastic and rings of ivalon reinforced by stainless steel. Twenty-four dogs were operated upon; there were seven long-term survivors and 17 dogs died within seven days. The immediate mortality was ascribed to suture insufficiency (3), pneumonia (3), error in anaesthesia (2), acidosis (6), haemorrhage from tracheostomy (1), embolism with hemiplegia (1), and haemothorax (1).
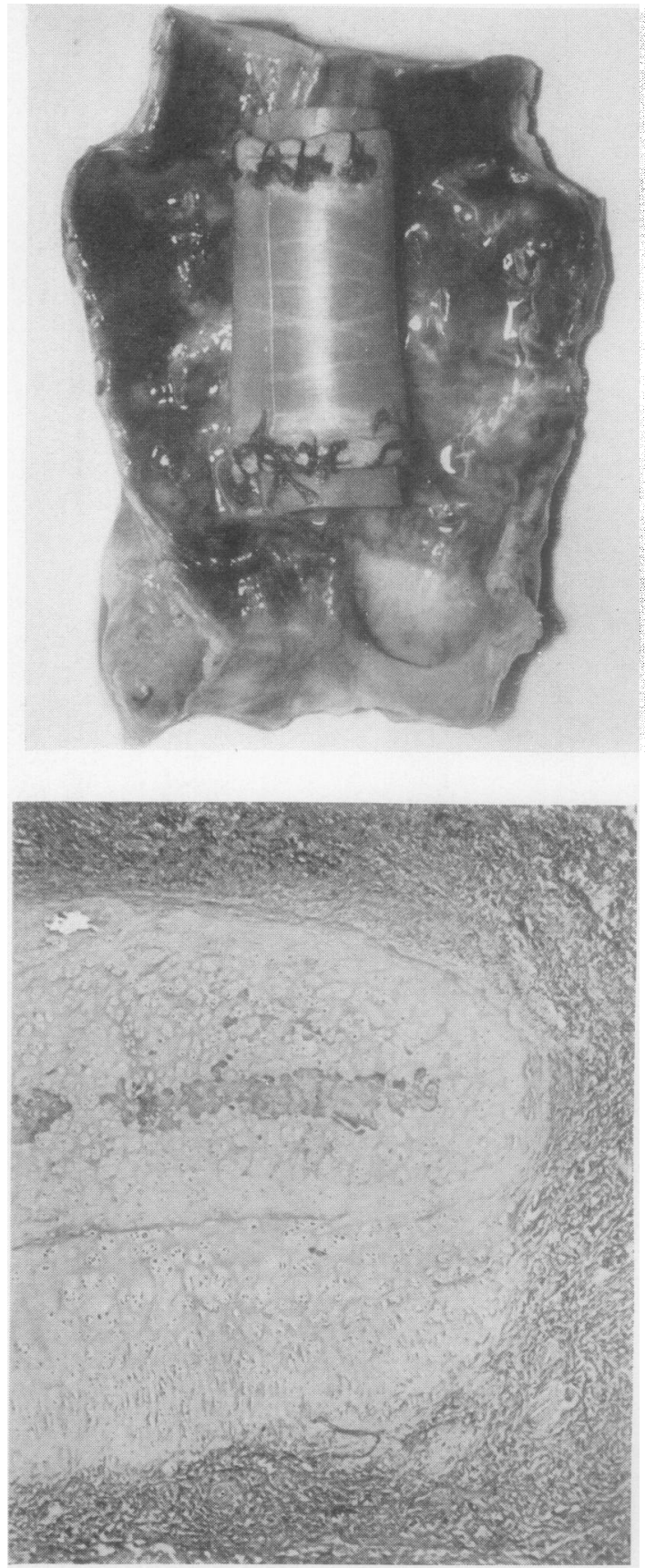

FIG. 3. (Above) Collapse of the unsupported new trachea after the inner tube of silastic had become dislodged 183 days after operation. (Below) Cartilage proliferation on the outer side of the tracheal ring close to the resectional margin. Weigert's haematoxylin and van Gieson, $\times 35$. 


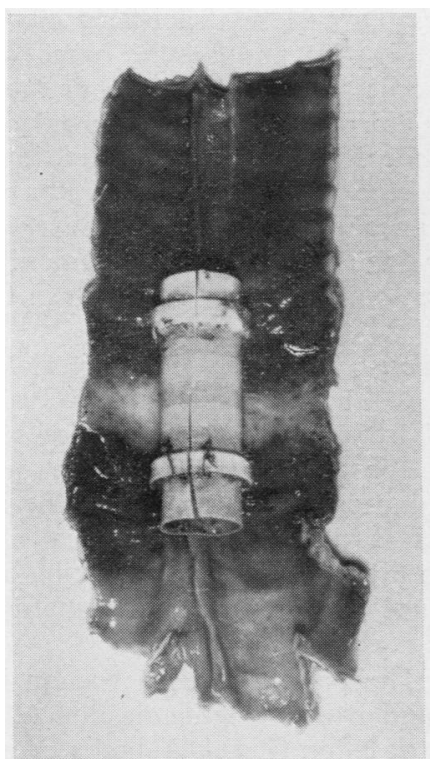

FIG. 4. Gross appearance of the trachea (dog 11) four years after resection of nine rings. The teflon prosthesis was found to be in place. The sewing ridge helped fixation of the prosthesis but caused some pressure necrosis.

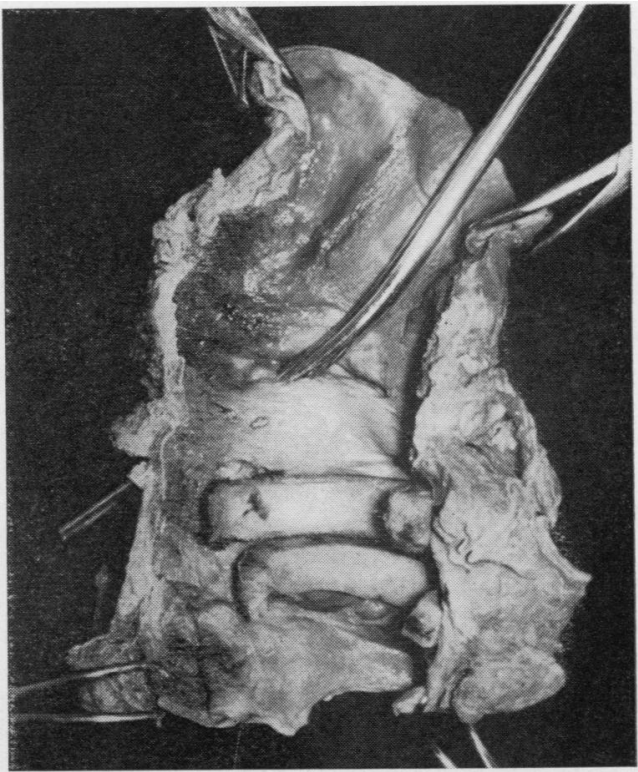

FIG. 5. Dog 22. A cannula is passed through the perfora tion to the oesophagus at the site of the cranial ivalon ring. None of the ivalon rings was healed in place 220 days after operation.

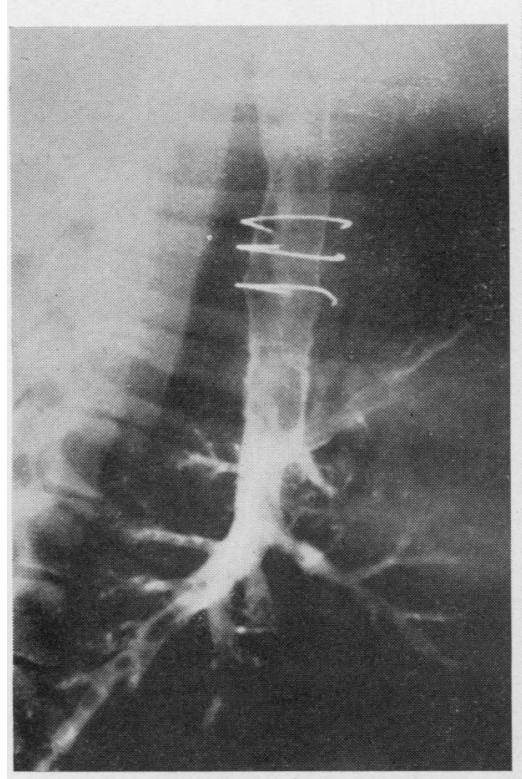

(a)

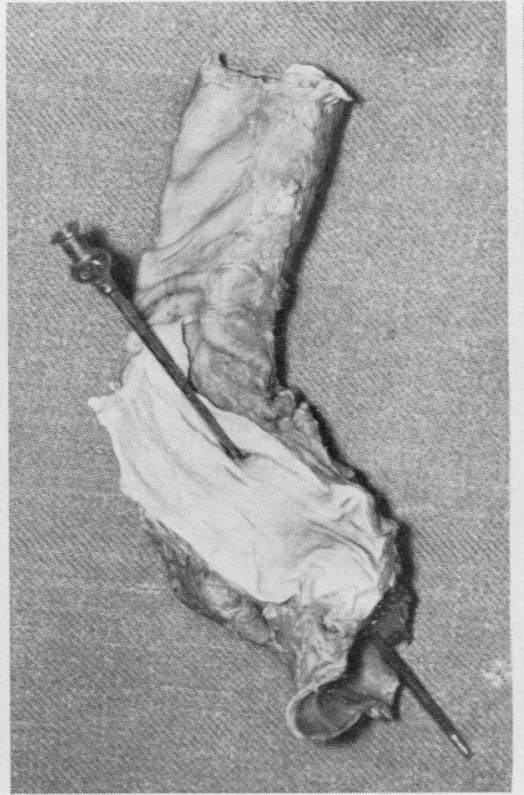

(b)

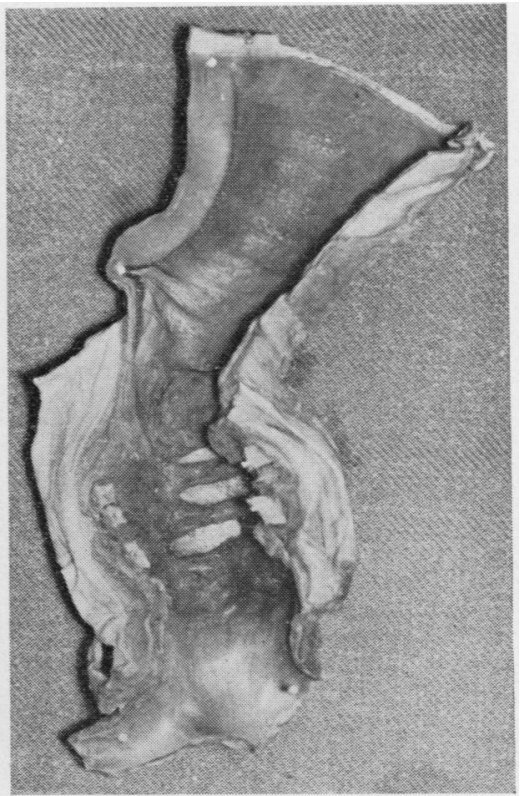

(c)

FIG. 6. (a) Bronchography of dog 26 one year after operation showed a good result with widely patent lumen and the rings in satisfactory position after removal of the prosthesis. (b) After removal of the inner tube by bronchoscopy a fistula to the oesophagus developed, causing death. (c) After one year the teflon rings were still not completely held in place but they were in direct communication with the lumen once the inner tube had been removed. 
Of the seven survivors, three dogs had late perforations of the oesophagus. In dogs 22 and 24 the perforation was caused by the ivalon ring reinforced by stainless steel wire, after 220 days (Fig. 5) and 194 days respectively. In dog 26 the oesophagus was perforated when the inner tube was removed by bronchoscopy 360 days after operation (Fig. 6).

Three other dogs had the inner tube removed by bronchoscopy, and in all three the ivalon rings were thereafter found to be loose in the lumen of

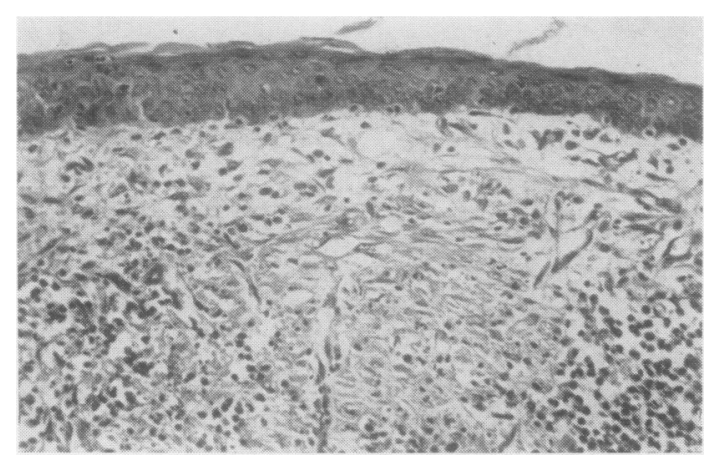

FIG. 7. Metaplastic squamous epithelium in the margin of the reconstructed part.

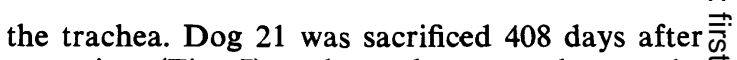
operation (Fig. 7) and on the same day as the bronchoscopic removal of the inner tube and two $\frac{}{\circ}$ rings. The third ring caused tracheal obstruction $\overline{\bar{N}}$. with dyspnoea. Dogs 23 and 27 died 15 days after $\widehat{\nabla}$ removal of the inner tube. The ivalon rings were found in an abscess in the trachea (Fig. 8). The ${ }^{\infty}$ remaining dog (25) died from pneumonia 123 days $\vec{\circ}$ after operation. The inner tube was in the correct $\vec{\overrightarrow{ }}$ position.

Conclusion An inner tube of silastic has $\underset{2}{\stackrel{\rho}{\vec{*}}}$ tendency to become displaced. Ivalon rings $\times$ reinforced by stainless steel are not suitable. In $\vec{\omega}$ two cases the rings perforated the oesophagus. $\frac{i}{\omega}$ When the inner tube was removed the rings were not healed in place but were usually found to ${ }_{0}$ be loose in the trachea and obstructing the airway. They did not prevent stricture formation.

GROUP B The prosthesis used was an inner tube $\vec{\oplus}$ of tefion and ivalon rings. One dog (28) with an inner tube of teflon (Fig. 1 D) had a bronchoscopy performed after 282 days. The teflon tube could not be removed in spite of several attempts being made. The dog died 20 days later. Necropsyo showed that the lungs were in good condition and the ivalon rings were partly healed in place $\unrhd$ (Fig. 9).

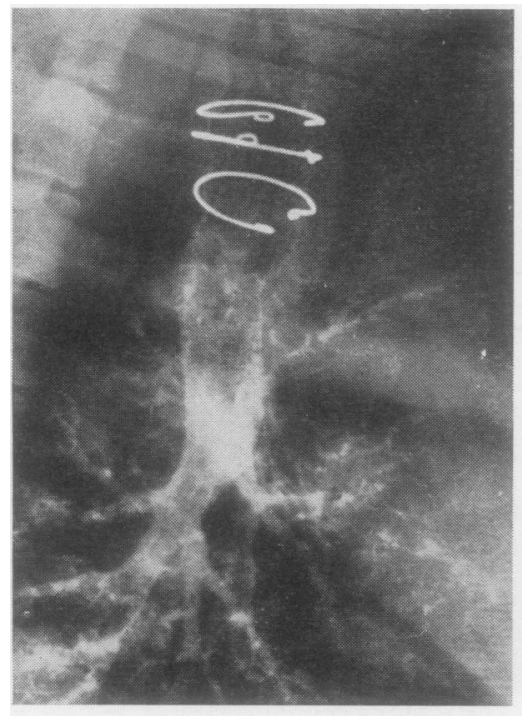

(a)

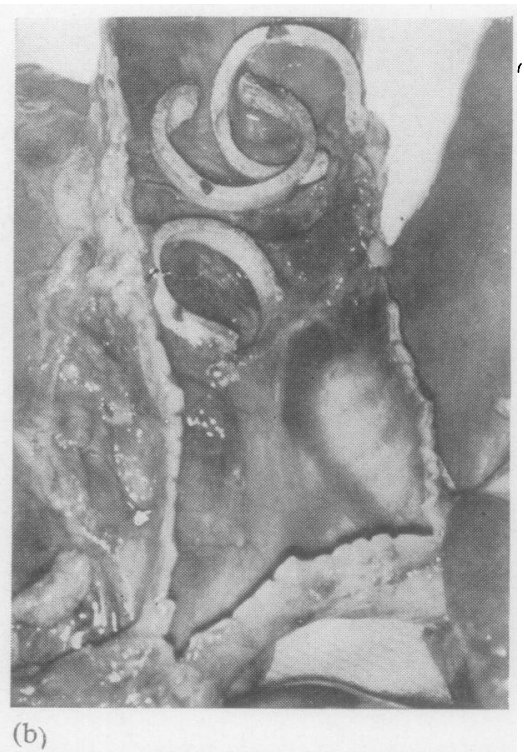

(b)

FIG. 8. Dog 27. (a) Bronchography 313 days after operation showed a wide open lumen and the ivalon rings in good position after removal of the prosthesis. (b) This dog died 15 days after removal of the inner tube. All the inner rings were lying loose in the trachea causing airway obstruction. 


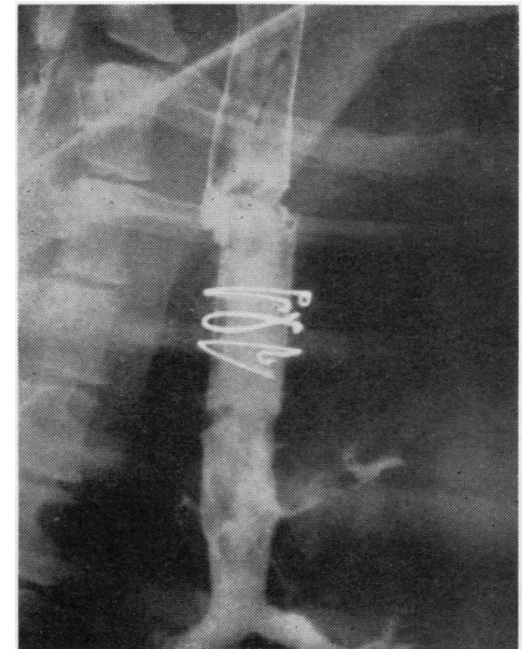

FIG. 9a

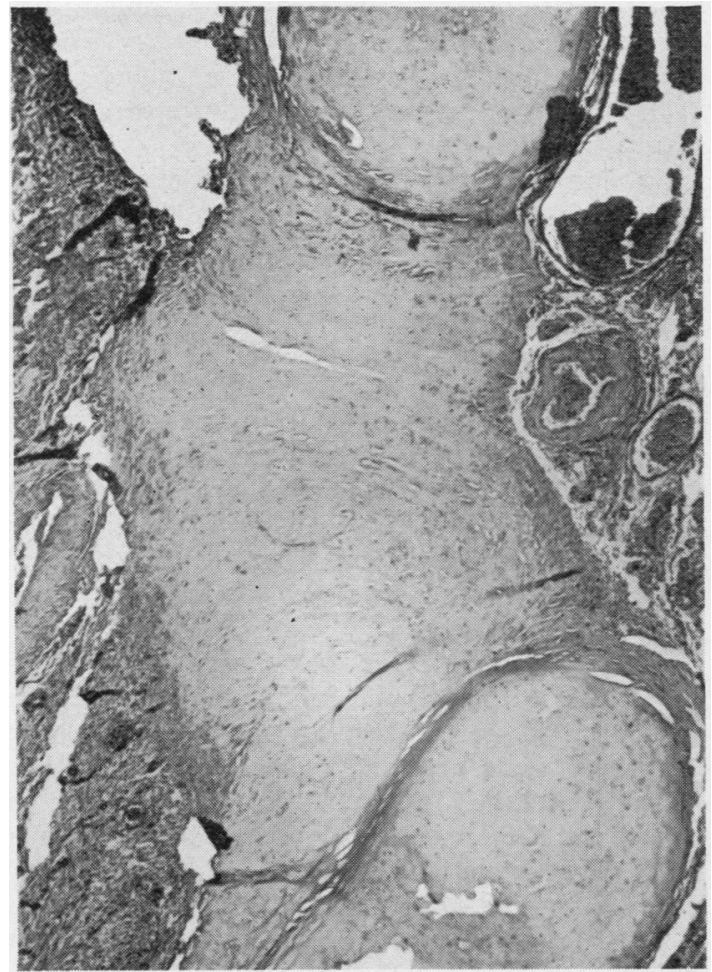

FIG. 9c

FIG. 9. Dog 28. (a) Bronchography shows a wide open tracheal prosthesis but the ivalon rings are too close together in the centre. (b) Necropsy specimen. The ivalon rings are only partly held in place after 282 days. (c) $A$ newly formed bridge of cartilage between two tracheal rings close to the resectional margin. Weigert's haematoxylin and van Gieson, $\times 33$.

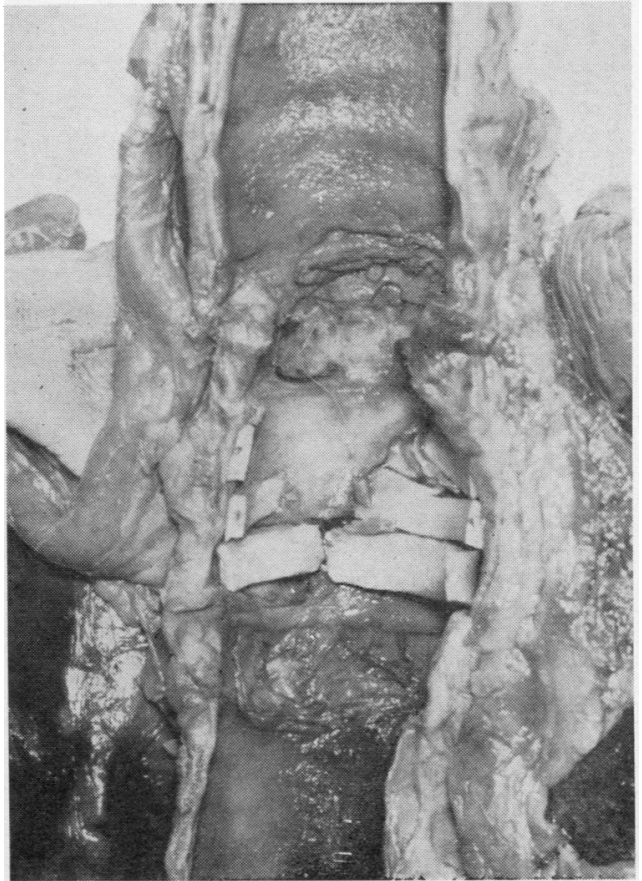

FIG. 9b

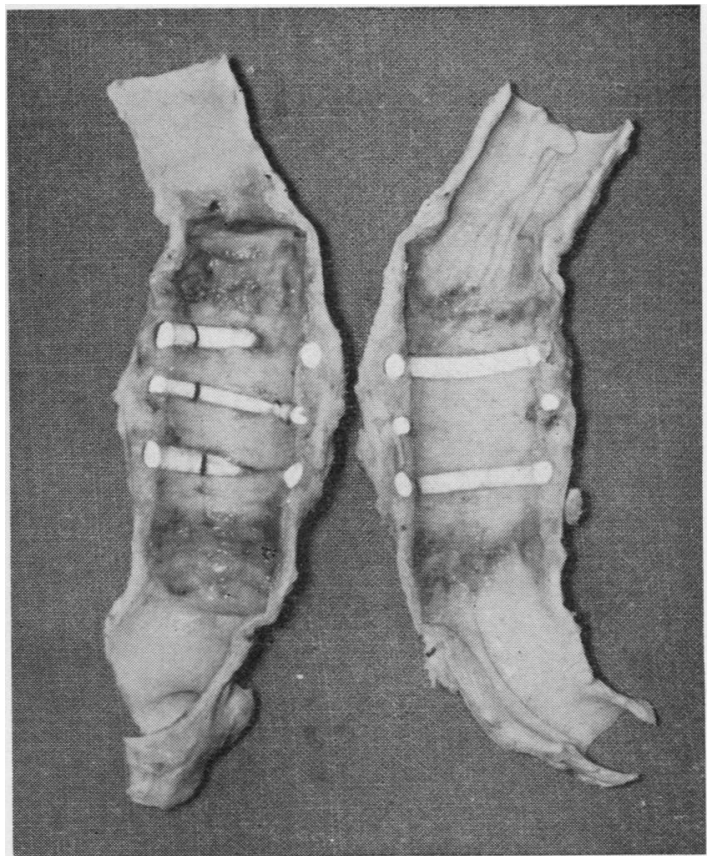

FIG. 10. Necropsy specimen from dog 12 sacrificed after 121 days. The teflon rings are only partly embedded in tissue. 
Conclusion A teflon tube with big extensions for suturing may firmly heal in place and it may be impossible to remove it owing to the extensions. The ivalon rings were not completely covered or invaded by fibrous tissue.

GROUP C The prosthesis used was an inner tube of silastic with teflon rings. Of eight dogs, three died, two from pneumonia, four and five days after operation, and one from the operation.

Five dogs survived. Of those, one (12) died 121 days after operation as a result of another operation performed by another team. The silastic tube was found to be in place but the teflon rings were not completely embedded in tissue (Fig. 10). The second dog (32) died from distemper after 109 days; the tube was in place. Three dogs $(13,15$, and 16) are still alive and well after six months.

GROUP D The prosthesis used was an inner tube of teflon with rings of teflon. Eighteen dogs were operated upon. Thirteen dogs died in the early post-operative period due to suture insufficiency (5), bronchopneumonia (3), distemper (3), and from an unknown cause (2).

Of the five survivors, one (14) died from distemper after 76 days (Fig. 11). Another (20) died after 226 days; one ring was well encapsulated. One dog (19) died 622 days after operation, and after that the inner prosthesis was

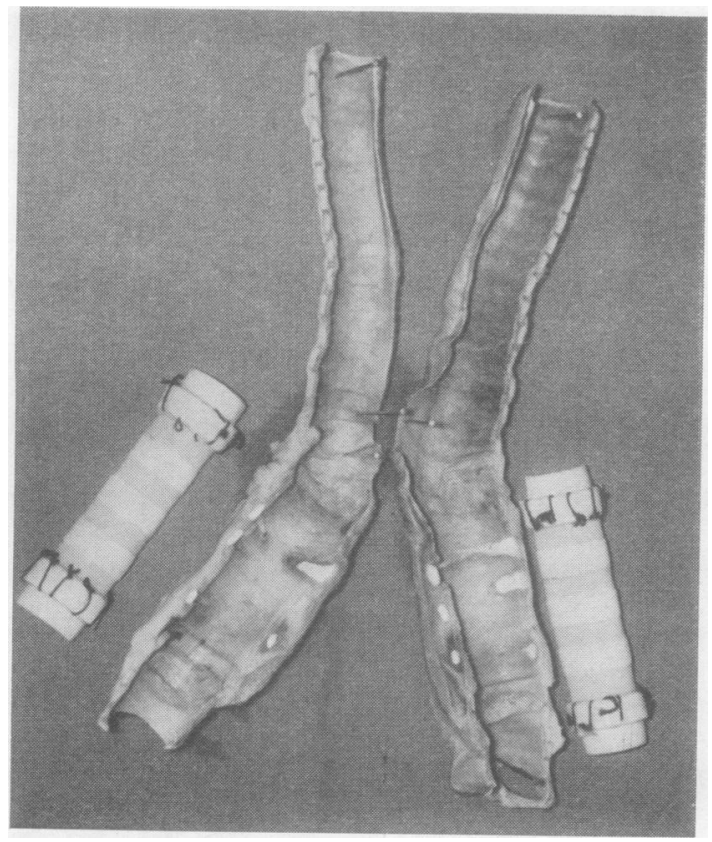

FIG. 11. Dog 14. After 76 days the teflon rings were already embedded in tissue. removed. Two dogs (17 and 47) died after 5 属 days and 1408 days (3 years 11 months) respectively. Necropsy showed that the teflos rings were well embedded (Figs. 12 and $131 . \overline{\frac{s}{5}}$

Conclusion Attempts to remove the teflo tubes with sewing extensions have not beem successful. On the other hand, it has been proved that fine rings of teflon can be embedded in the pedicled pericardium and mediastinal tissue to form a rigid tube with a smooth inner surface.

PATHOLOGY The degree of the changes in the reconstructed part of the trachea and adjacent tissues can be seen in Table I. Only a few added comments are necessary.

The inflammation in the reconstructed part of the trachea often had the appearance of granulation tissue. In some cases a capillary-rich granula $\subseteq$ tion tissue could be seen protruding fungous-like into the tracheal lumen.

The connective tissue was in many case $\$$ hyalinized and sclerotic with the appearance of scar tissue.

Foreign body reaction could be seen around the suture or prosthesis material. Only a feno foreign body giant cells have usually beeno observed.

Cartilage proliferation of a rather high degree $\overrightarrow{\overrightarrow{0}}$ was seen in several cases close to the anastomosis. Sometimes there was a proliferation of the outer side of the cartilage rings. In some cases therewas a proliferation between two rings connecting them with each other, and in others small cartilage fragments were seen in the connective tissue in the vicinity of the cartilage rings which appeared 3 . to be newly formed. The newly formed cartilage rings were often fibrous.

Epithelial regeneration was observed in only a few cases within areas in the middle of the $\mathrm{S}$ reconstructed part. More often, endothelial-like cells were seen on the surface of the sclerotic connective tissue. In such cases inflammation in $N$ the connective tissue was only slight, if present $N$ at all. The origin of these cells is obscure. They $N$ probably originate from fibroblasts in the granula- $\omega$ tion tissue or from fibroblasts or fibrocytes of the grafted tissue. There is no real proof that these cells are regenerating epithelial cells.

\section{DISCUSSION}

From the results summarized in Table II it is $\frac{\stackrel{\rho}{\mathbb{D}}}{\sigma}$ evident that teflon was tolerated as an inner tube $\stackrel{0}{\circ}$ better than silastic, and it functioned well for four years in two dogs. Furthermore, tubes of silastic $\delta$ did not prevent pressure necrosis with oesophageal perforations. A teflon tube has thinner walls and 흘 


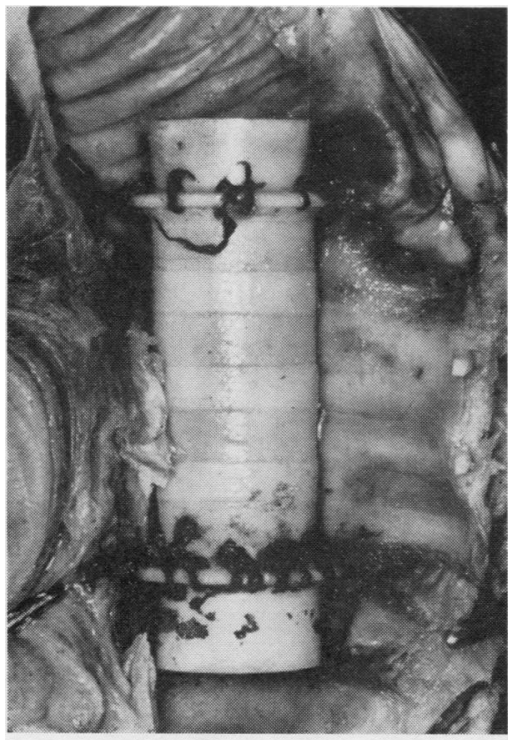

(a)

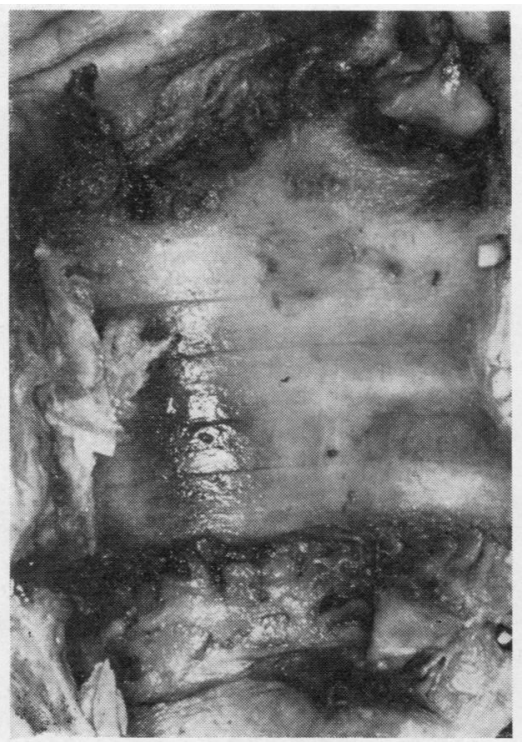

(b)
FIG. 12. Dog 47. (a) The teflon inner tube was found to be in place after 505 days, and all the teflon rings were well embedded. (b) Afier removal of the inner tube a smooth surface was found on the newly created trachea, well supported by the embedded teflon rings. (c) Endothelial-like cells in the surface of the reconstructed part. Haematoxylin and eosin, $\times 900$. (d) Connective tissue surrounding a gap below a teflon ring with two small rests of teflon and foreign body granuloma. Weigert's haematoxylin and van Gieson, $\times 560$.

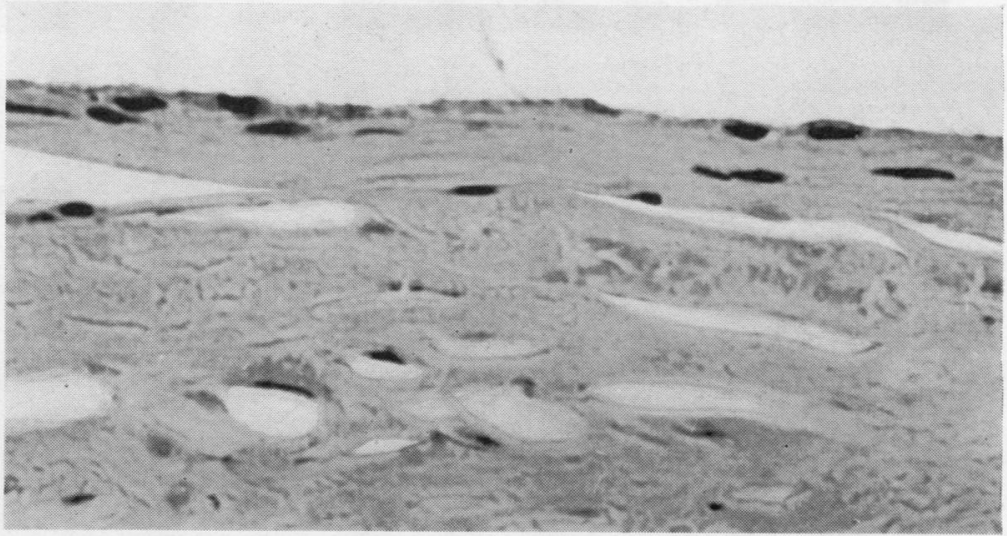

(c)

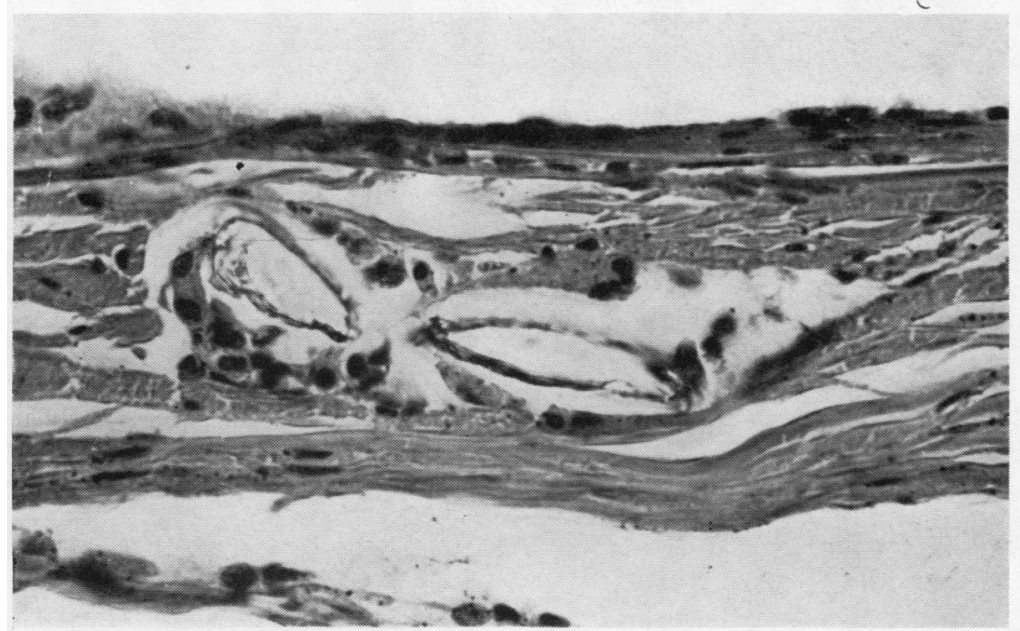

(d) 


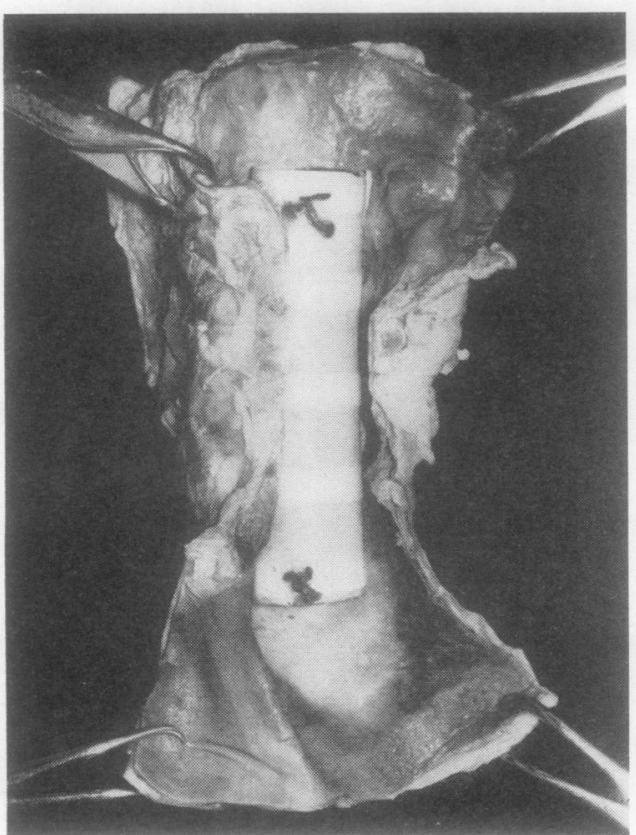

(a)

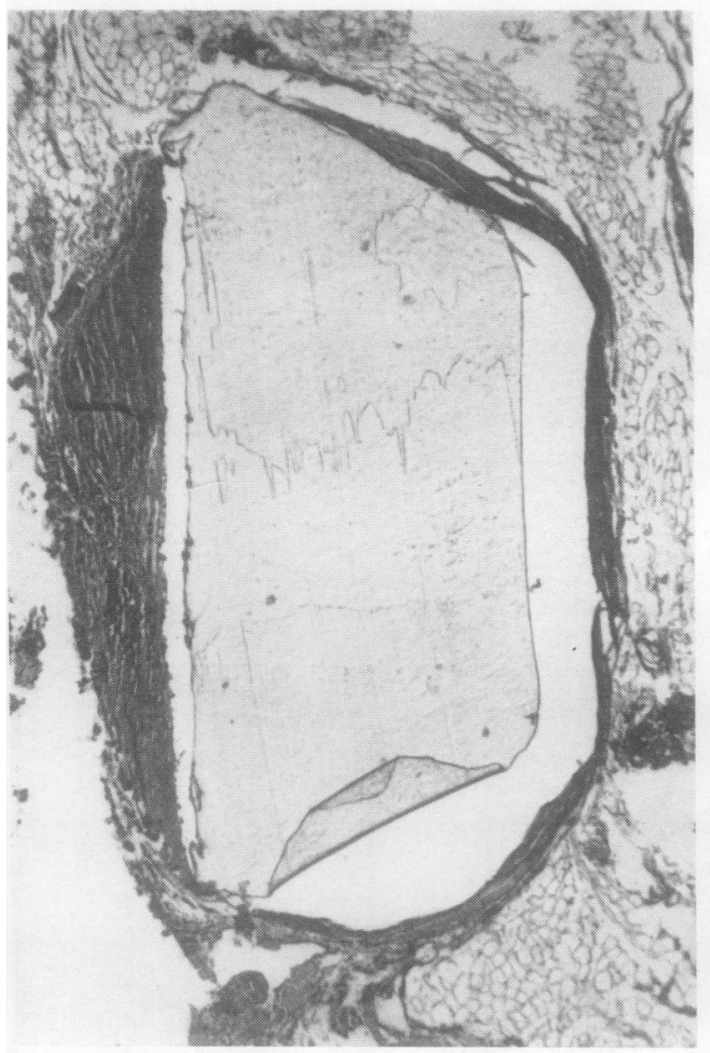

(c)

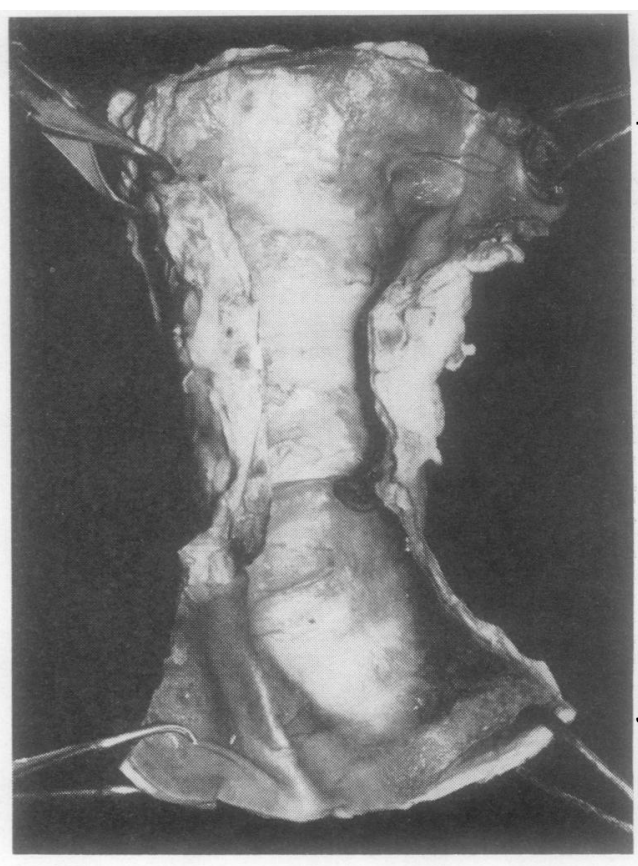

(b)
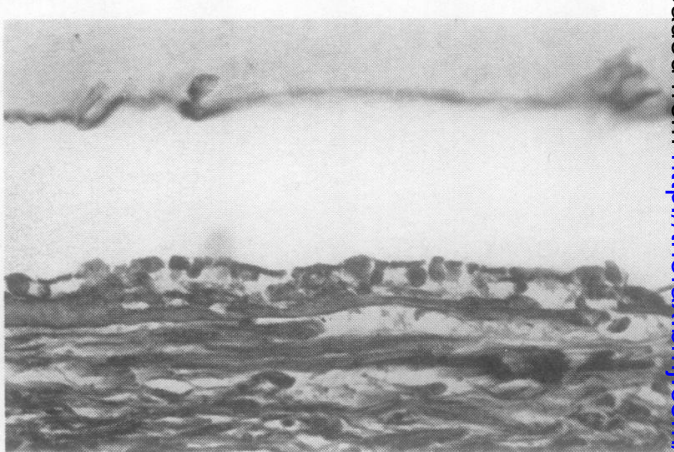

(d)

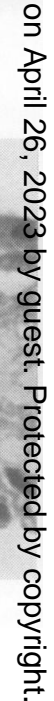


FIG. 13. Dog 17. (a) The inner teflon tube was left in place for 3 years 11 months. (b) The teflon rings were wel! embedded, and a rigid, newly formed trachea with a smooth inner surface was found. In this dog there was no sewing ridge in the tracheal tube, and there was a smooth wall between the newly formed and the old trachea. (c) $A$ teflon ring with a connective tissue capsule in the tracheal wall. Weigert's haematoxylin and van Gieson, $\times 35$. (d) The margin of a teflon ring with slight inflammatory reaction in the surrounding connective tissue. Weigert's haematoxylin and van Gieson, $\times 360$. (e) Regenerating epithelial cells in the surface of the reconstructed part. Haematoxylin and eosin, $\times 900$. a greater lumen is therefore obtained. Mucus did not stick to either material. Ivalon was found to be an unsuitable material for the rings as none became embedded and healed in place. The teflon rings, however, were embedded in the newly formed trachea and assumed an appearance and function similar to those of the tracheal cartilage. The fact that teflon tubes have functioned well and also that they have been well tolerated for up to four years is encouraging. The technique of suturing with the tubes inside the end of the trachea prevented suture granuloma with stricture at the anastomosis. In human beings, a pedicled flap of pleura could be used instead of a pedicled

TABLE I

\begin{tabular}{|c|c|c|c|c|c|c|c|c|c|c|c|c|c|c|c|c|}
\hline \multirow[b]{3}{*}{ 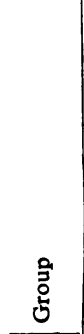 } & \multirow[b]{3}{*}{$\begin{array}{l}\dot{0} \\
\dot{z} \\
\dot{0}\end{array}$} & \multirow[b]{3}{*}{ 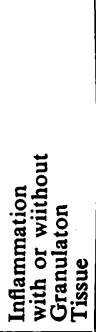 } & \multirow[b]{3}{*}{ 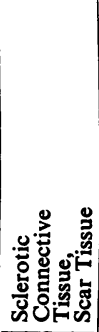 } & \multirow[b]{3}{*}{ 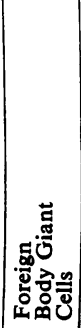 } & \multirow[b]{3}{*}{ 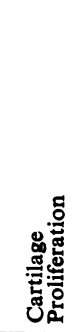 } & \multirow[b]{3}{*}{ 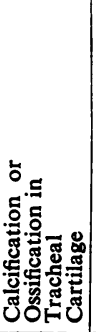 } & \multirow{2}{*}{\multicolumn{4}{|c|}{$\begin{array}{l}\text { Prosthesis and } \\
\text { Reaction Against } \\
\text { the Prosthesis } \\
\text { Material }\end{array}$}} & \multirow[b]{3}{*}{ 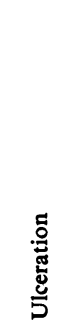 } & \multicolumn{5}{|c|}{ Tracheal Mucous Membrane } \\
\hline & & & & & & & & & & & & \multicolumn{2}{|c|}{$\begin{array}{c}\text { Central } \\
\text { Part }\end{array}$} & \multicolumn{3}{|c|}{ Margin } \\
\hline & & & & & & & 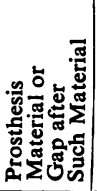 & 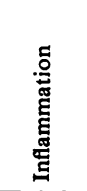 & 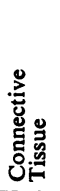 & 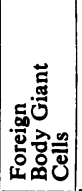 & & 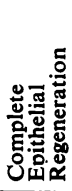 & 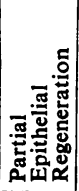 & 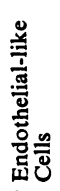 & 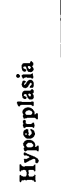 & 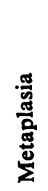 \\
\hline ontrol & $\begin{array}{r}4 \\
5 \\
11\end{array}$ & $\begin{array}{l}+++ \\
+++ \\
++(+)\end{array}$ & $\begin{array}{l}+++ \\
++ \\
+++\end{array}$ & $\begin{array}{c}0 \\
(++) \\
0\end{array}$ & +++ & $\begin{array}{c}+ \\
+ \\
(+)\end{array}$ & $\begin{array}{l}0 \\
0 \\
0\end{array}$ & & & & $\begin{array}{c}+++ \\
+++ \\
++\end{array}$ & $\begin{array}{l}0 \\
0 \\
0\end{array}$ & $\begin{array}{l}0 \\
0 \\
0\end{array}$ & $\begin{array}{l}\mathbf{0} \\
\mathbf{0} \\
+\end{array}$ & $\begin{array}{c}+ \\
++ \\
0\end{array}$ & $\begin{array}{l}+ \\
0 \\
0\end{array}$ \\
\hline $\mathbf{A}$ & $\begin{array}{l}21 \\
22 \\
23 \\
24 \\
25 \\
26\end{array}$ & $\begin{array}{c}+++ \\
+++ \\
+++ \\
+++ \\
++ \\
+++\end{array}$ & $\begin{array}{c}+++ \\
+++ \\
++ \\
+++ \\
+++ \\
++\end{array}$ & $\begin{array}{l}+\dagger \\
0 \\
+ \\
+\dagger \\
0 \\
+\end{array}$ & $\begin{array}{c}0 \\
+(+) \\
+ \\
+(+) \\
(+) \\
+\end{array}$ & $\begin{array}{c}++ \\
+++ \\
+ \\
+ \\
+ \\
+++\end{array}$ & $\begin{array}{l}+ \\
0 \\
0 \\
+ \\
+ \\
0\end{array}$ & $\begin{array}{c}+++ \\
+ \\
+\end{array}$ & $\begin{array}{l}++ \\
++ \\
++\end{array}$ & $\begin{array}{l}+ \\
\mathbf{0} \\
\mathbf{0}\end{array}$ & $\begin{array}{c}++ \\
+++ \\
++ \\
++ \\
++ \\
++\end{array}$ & $\begin{array}{l}\mathbf{0} \\
0 \\
0 \\
0 \\
0 \\
0\end{array}$ & $\begin{array}{l}+ \\
0 \\
+ \\
0 \\
0 \\
+\end{array}$ & $\begin{array}{c}0 \\
+ \\
(+) \\
+ \\
(+) \\
(+)\end{array}$ & $\begin{array}{l}+ \\
0 \\
0 \\
0 \\
0 \\
0\end{array}$ & $\begin{array}{c}++ \\
0 \\
(+) \\
0 \\
0 \\
(+)\end{array}$ \\
\hline B & 28 & ++ & +++ & $+t$ & +++ & + & + & $+(+)$ & ++ & + & ++ & 0 & 0 & $(+)$ & 0 & $(+)$ \\
\hline $\mathbf{C}$ & $\begin{array}{l}12 \\
32\end{array}$ & $\begin{array}{l}+++ \\
+++\end{array}$ & $\begin{array}{l}+++ \\
+++\end{array}$ & + & $\begin{array}{l}++ \\
++\end{array}$ & $\stackrel{+}{(+)}$ & + & + & + & + & +++ & $\begin{array}{l}0 \\
0\end{array}$ & $\begin{array}{l}0 \\
0\end{array}$ & + & $\stackrel{+}{0}$ & + \\
\hline D & $\begin{array}{l}14 \\
17 \\
47\end{array}$ & $\begin{array}{c}++(+) \\
++ \\
+*\end{array}$ & $\begin{array}{l}+++ \\
++ \\
+++\end{array}$ & $\begin{array}{c}+ \\
+ \\
0\end{array}$ & $\begin{array}{c}+ \\
+ \\
++\end{array}$ & $\begin{array}{c}+(+) \\
(+) \\
+++\end{array}$ & $\begin{array}{l}+ \\
+ \\
+\end{array}$ & $\begin{array}{l}++ \\
(+) \\
(+)\end{array}$ & $\begin{array}{l}+ \\
++ \\
++\end{array}$ & $\begin{array}{c}0 \\
(+\stackrel{+}{+})\end{array}$ & $\begin{array}{l}++ \\
+ \\
+\end{array}$ & $\begin{array}{l}0 \\
0 \\
0\end{array}$ & $\begin{array}{l}0 \\
+ \\
0\end{array}$ & $\begin{array}{c}(+) \\
+ \\
+\end{array}$ & $\begin{array}{l}0 \\
0 \\
0\end{array}$ & $\begin{array}{l}\mathbf{0} \\
\mathbf{0} \\
+\end{array}$ \\
\hline
\end{tabular}

* $=$ in limited areas of higher degree; $t=$ suture granuloma.

TABLE II

RESULTS OF TRACHEAL REPLACEMENT

\begin{tabular}{|c|c|c|c|c|c|c|c|c|c|}
\hline \multirow{2}{*}{ Group } & & \multirow{2}{*}{$\begin{array}{l}\text { No. of } \\
\text { Dogs }\end{array}$} & \multirow{2}{*}{$\begin{array}{l}\text { Immediate } \\
\text { Mortality }\end{array}$} & \multirow{2}{*}{$\begin{array}{l}\text { Sur- } \\
\text { vivors }\end{array}$} & \multirow{2}{*}{$\begin{array}{c}\text { Per- } \\
\text { foration }\end{array}$} & \multirow{2}{*}{$\begin{array}{l}\text { Longest } \\
\text { Survival }\end{array}$} & \multicolumn{2}{|c|}{ Fixation } & \multirow{2}{*}{ Function } \\
\hline & & & & & & & $\begin{array}{l}\text { Inner } \\
\text { Tube }\end{array}$ & Rings & \\
\hline $\begin{array}{l}\text { Control } \\
\text { A } \\
\text { B } \\
\text { C } \\
\text { D }\end{array}$ & 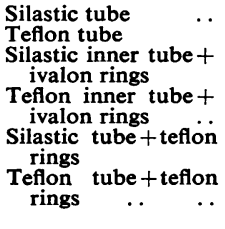 & $\begin{array}{r}1 \\
8 \\
18\end{array}$ & $\begin{array}{r}0 \\
0 \\
17 \\
0 \\
3 \\
13\end{array}$ & $\begin{array}{l}1 \\
5 \\
5\end{array}$ & $\begin{array}{l}0 \\
0 \\
0\end{array}$ & $\begin{array}{l}183 \text { days } \\
4 \text { years } \\
408 \text { days } \\
282 \text { days } \\
\text { Still living } \\
6 \text { months } \\
4 \text { years }\end{array}$ & $\begin{array}{l}\text { Bad } \\
\text { Good } \\
\text { Bad } \\
\text { Good } \\
\text { Good } \\
\text { Good }\end{array}$ & $\begin{array}{l}\overline{-} \\
\text { Bad } \\
\text { Bad } \\
\text { Good } \\
\text { Good }\end{array}$ & $\begin{array}{l}\text { Stenosis } \\
\text { Excellent } \\
\text { Stenosis when inner } \\
\text { tube removed } \\
\text { Good } \\
\text { Good } \\
\text { Good }\end{array}$ \\
\hline
\end{tabular}


flap of pericardium. The shape of the teflon prosthesis used permitted excellent fixation. However, the teflon extension injured the surrounding tissue and rings when the inner tube was removed. The function of the outer tube as a trachea with supporting teflon rings could not be tested. The new principle of creating the trachea as an outer tube of thin supporting teflon rings placed at short intervals over a pedicled flap of pericardium has proved to be possible. The rings are embedded in tissue during the time the inner tube functions as a trachea. The results seem promising in this very difficult field of tracheal reconstruction.

\section{SUMMARY}

A new principle for tracheal reconstruction is presented. Thin teflon rings are embedded in the mediastinal tissue over a pedicled flap of pericardium placed over an inner tube of teflon for immediate function. The observations from dog experiments carried on over a period of four years are reported.

\section{REFERENCES}

Aronstam, E. M., Nims, R. M., and Winn, D. F. (1961). Studies in segmental replacement of the thoracic trachea. J. surg. Res., 1 108 .

Barclay, R. S., McSwan, N., and Welsh, T. M. (1957). Tracheal reconstruction without the use of grafts. Thorax, 12, 177.

Beall, A. C., Harrington, O. B., Greenberg, S. D., Morris, G. C., and Usher, F. C. (1962). Tracheal replacement with heavy Marlex mesh. Arch. Surg., 84, 390.

Bell, J. W. (1960). Experimental repair of tracheal defects with gallbladder mucosa. Dis. Chest, 38, 140.

Björk, V. O. (1955). Left-sided bronchotracheal anastomosis. $J$. thorac. Surg., 30, 492.

and Rodriguez, L. E. (1958). Reconstruction of the trachea and its bifurcation. Ibid., 35,596 .

Brewer, L. A., and Bai, A. F. (1955). Surgery of the bronchi and trachea. Experience with the pedicled pericardial fat graft reintrachea. Experience with the pedic

Burnett, C. A., Stanley, A. L., and Stringer, C. J. (1962). Tracheal replacement with polyethylene tubes and report of case. J. Maine med. Ass., 53, 112 .

Clagett, O. T. (1956). Disc. Keshishian et al. J. thorac. Surg., 32, 707. Grindlay, J. H., and Moersch, H. J. (1948). Resection of the trachea. Arch. Surg., 57, 253.

Cotton, B. H., and Penido, J. R. F. (1952). Resection of the trachea for carcinoma. $J$. thorac. Su"g., 24, 231.

Crafoord, C., Björk, V. O., and Hilty, H. (1954). Zur Bronchialresektion und broncho-trachealen Anastomose bei tuberkulöser Bronchialstenose. Thoraxchirurgie, $2,1$.
Craig, R. L., Holmes, G. W., and Shabart, E. J. (1953). Trache resection and replacement with a prosthesis. J. thorac. Surg $25,384$.

Cummins, C. F. A., and Waterman, D. H. (1957) The managemero of tracheal stenosis, with a case report. Dis. Chest, 31, 375 .

Daniel, R. A. (1948). The regeneration of defects of the trachea an bronchi. J. thorac. Surg., 17, 335.

Davies, O. G., Edmiston, J.' M., and McCorkle, H. J. (1952). Th repair of experimental tracheal defects with fresh and preserved homologous tracheal grafts. Ibid., 23, 367.

Dor, J., and Carcassonne, M. (1958). Contribution expérimentale ì la réparation des pertes de substance de la trachée et des broncheø Ann. Chir. 12, 1041.

Ekestrc̈m, S. (1956). Experimental reconstruction of the intrathoracic trachea. Acta chir. scand., 110, 367.

(1958). Reconstruction of the Intrathoracic Trachea. Ncrdis Rotogravir, Stockholm.

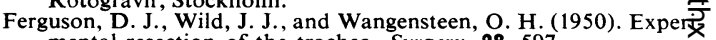
mental resection of the trachea. Surgery, 28, 597.

Greenberg. S. D. (1960). Tracheal reconstruction. Arch. Otolaryng $\overrightarrow{C O}$ 72,565 .

- and Willms, R. K. (1962). Tracheal prostheses. Ibid., 75, 335. +

Harrington, O. B., Beall, A. C., Morris, G. C., and Usher, F. (U) (1962). Circumferencial replacement of the trachea with Marles mesh. Amer. Surg., 28, 217.

Jackson, T. L., O'Brien, E. J., Tuttle, W., and Meyer, J. (19509 The experimental use of homogenous tracheal transplants in the restoration of continuity of the tracheobronchial tree. $J$. thorac Surg., $20,598$.

Jesseph, J. E., Stevenson, J. K., Harkins, H. N., and Merendin K. A. (1956). Human measurements involved in tracheobronch resection, reconstruction and prosthetic replacement: A preliminary report on ivalon sponge. Surg. Forum, 7, 218.

Kay, E. B. (1952). Disc. Cotton and Penido. J. thorac. Surg., 24, 230 Keshishian, J. M., Blades, B., and Beattie, E. J. (1956). Ibid., 32, 70

Kramish, D., Rutherford, R. B., Morfit, H. M., and Lunt, J. (1961) Bridging tracheobronchial tree defects with tefion prosthese Arch. Surg. 82, 878. Arch. Surg., 82, 878

Longmire, W.P., Jr. (1948). The repair of large defects of the trachea Ann. Otol. (St. Louis), 57, 875.

Mathey, J., Denis, B., and Binet, J. P. (1960). Chirurgie des tumeu primitives de la trachée. Ann. Crir., 14, 1343.

Michelson, E., Solomon, R., Maun, L., and Ramirez, J. (1961ํㅐ Experiments in tracheal reconstruction. J. thorac. cardiovas $\mathbb{Q}$ Surg., 41, 748.

Moncrief, W.' H., and Salvatore, J. E. (1958). An improved trache prosthesis. Surg. Forum, 9, 350.

Morfit, H. M., Neerken, A. J., Prevedel, A., I iddle, E. B., and Kircher, L. (1954). Experimental principles of repair of comple tracheal defects. Ibid., 5, 823.

Paulson, D. L., and Shaw, R. B. (1955). Bronchial anastomosis and. bronchoplastic procedures in the interest of preservation of lun bronchoplastic procedures in the
tissue. J. thorac. Surg., $29,238$.

Pressman, J. J., and Simon, M. B. (1958). Observations upon the experimental repair of the trachea using autogenous aorta and polyethylene tubes. Surg. Gynec. Obstet., 106, 56.

Ravitch, M. M. (1951). Discussion on Gebauer, P. W. J. thorac. Surgo 22, 583 .

Rob, C. G., and Bateman, G. H. (1949). Reconstruction of the trachea and cervical oesophagus. Preliminary report. Brit. $\mathbb{O}$

Surg., 37, 202.
and Bromley, L. L. (1953). Reconstruction of the trachea Thurax, 8,269.

Rush, B. F., and Cliffton, E. E. (1956). Experimental reconstructio of the trachea with bladder mucosa. Surgerv, 40, 1105.

Swift, E. A., Grindlay, J. H., and Clagett, O. T. (1952). The repair of tracheal defects with fascia and Tantalum mesh.J. thorac. Surgo 24, 482.

Taber, R. E., and Tomatis, L. (1958). Experimental and clinic N utilization of a prosthesis for replacement of the trachea. Arcos Surg., 77, 576. 